\title{
A 'Swedish Offensive' at the World's Fairs: Advertising, Social Reformism and the Roots of Swedish Cultural Diplomacy, 1935-1939
}

\author{
Nikolas Glover ${ }^{1}$ (D) and Andreas Mørkved Hellenes ${ }^{2}$ (D) \\ ${ }^{1}$ Department of Economic History, Uppsala University, Box 513, 75120 Uppsala, Sweden and ${ }^{2}$ Aarhus University, School of \\ Culture and Society, Jens Chr. Skous Vej 5, Building 1461, 8000 Aarhus C, Denmark \\ nikolas.glover@ekhist.uu.se; amh@cas.au.dk
}

While recent scholarship has highlighted how participating countries at the interwar world's fairs competed by displaying ideological versions of modernity, the alternative national projections of smaller states have received less attention. This study of the Swedish national pavilions from Brussels 1935 via Paris 1937 to New York 1939 analyses how a loose but well-connected network of communicators over the course of three fairs responded to, and used, the evolving trends at these international mega-events. In the threatening international atmosphere of the late 1930s, the network convinced the Swedish government to seize the opportunities opened up by the crises of capitalism and democracy. The 1937 and 1939 pavilions showcased Sweden at the world's fairs as an example of the successful handling of economic and socio-political crisis, and the experience had a formative impact on the post-war institutionalisation of Swedish cultural diplomacy.

In 1936 some of the most prominent names in the Swedish Arts and Crafts Society (Svenska Slöjdföreningen) urged their government to seize the moment at the 1937 World's Fair in Paris. ${ }^{1}$ They declared that the growing 'foreign interest in Sweden' in general, and in its modern architecture and decorative arts in particular, made the time ripe for a broad Swedish 'offensive.' ${ }^{2}$ In their view, a golden opportunity was at hand since Hitler's rise to power. By staging a comprehensive display of contemporary Swedish society in Paris, Sweden was in a position to fill the international leader seat' that thereby had been vacated. ${ }^{3}$ This call would be heeded by the Swedish government, which for the first time invested substantial public resources in creatively staged and well-received pavilions at the Paris International Exposition (1937) and the New York's World's Fair (1939).

This article focuses on the two Swedish pavilions presented in Paris and New York in the late 1930s and contrasts them with their immediate predecessor in Brussels (1935). This allows us to do make

\footnotetext{
1 Founded in 1845, the Swedish Arts and Crafts Society in 1976 adopted its current name, Svensk Form. As part trade association, part mouthpiece for social reforms, the Arts and Crafts Society resembled the German Association of Craftsmen (Deutscher Werkbund, founded 1907) and the Design and Industry Association in the United Kingdom (1915). See for example Helena Kåberg, 'An Introduction to Gregor Paulsson's Better Things for Everyday Life', in Lucy Creagh, Helena Kåberg and Barbara Miller Lane, eds., Modern Swedish Design: Three Founding Texts (New York: Museum of Modern Art, 2008), 63; John V. Maciuika, Before the Bauhaus: Architecture, Politics and the German State 1890-1920 (New York: Cambridge University Press, 2005); D. L. Mahieu, A Culture for Democracy: Mass Communication and the Cultivated Mind in Britain between the Wars (Oxford: Oxford University Press, 1988), 157-8.

2 Hald and Stavenow to Kommerskollegium, 7 Jan. 1936, Series F1, Vol. 9, Svensk Forms arkiv (SvF), Centrum för näringslivshistoria (CfN), Stockholm. See also Gotthard Johansson, 'Sverige och funktionalismens framtid', Svenska Dagbladet, 6 Sept. 1935.

3 Hald and Stavenow to Kommerskollegium, 7 Jan. 1936, Series F1, Vol. 9, SvF, CfN.

(C) The Author(s), 2020. Published by Cambridge University Press. This is an Open Access article, distributed under the terms of the Creative Commons Attribution licence (http://creativecommons.org/licenses/by/4.0/), which permits unrestricted re-use, distribution, and reproduction in any medium, provided the original work is properly cited.
} 
two contributions. Firstly, we broaden the perspective on the roots of official Swedish cultural diplomacy, which hitherto have been traced back to the interwar institutionalisation of academic exchanges and the associated official ethno-linguistic efforts to 'preserve Swedishness abroad'. ${ }^{4}$ In the parallel development dealt with here, we show how a loose network of social reformists received substantial government support to combine socially informative displays with selling presentations of handicraft and consumer wares. This resulted in professionally designed, media-sensitive projections of Sweden as a modern society catering to democratic citizens and rational consumers alike. ${ }^{5}$ These themes would play a prominent role when 'cultural exchange' was defined and institutionalised as a distinct policy field in Sweden immediately after the Second World War. ${ }^{6}$

Secondly, by examining how a peripheral European democracy sought to utilise international exhibitions as a means to exploit the geopolitical ramifications of international crises, we also contribute to the growing literature on the relationship between the emergence of state-sponsored interwar cultural relations and the looming threat of totalitarianism. ${ }^{7}$ Small states have historically had limited opportunities to attract the attention of foreign decision makers and influence public opinion overseas. Their chances of achieving impact have been highly dependent on external circumstances. ${ }^{8}$ The economic and political turmoil of the 1930s is an example of this, as it briefly altered the playing field in international cultural relations. Its uneven outcomes around the world meant that some states that hitherto had been quite peripheral to international debates were suddenly thrust into the limelight. Sweden, one of the first countries to officially recover from the Great Depression in 1934, provides a case in point.

Several historians have studied how Sweden's rapid recovery drew many people's attention to the Nordic countries in general and Sweden in particular. ${ }^{9}$ A profusion of books, reports and articles were published, including influential journalistic accounts written for a broader public like Marquis W. Childs' Sweden: The Middle Way (1936) and Émile Schreiber's Heureux scandinaves! (1936). ${ }^{10}$ Childs' bestselling intervention in the domestic political debates of New Deal United States firmly

4 Andreas Åkerlund, Mellan akademi och kulturpolitik: Lektorat i svenska språket vid tyska universitet 1906-1945 (Uppsala: Acta Universitatis Upsaliensis, 2010); Andreas Åkerlund, 'The Nationalisation of Swedish Enlightenment Activities Abroad', in Louis Clerc, Nikolas Glover and Paul Jordan, eds., Histories of Public Diplomacy and Nation Branding in the Nordic and Baltic Countries: Representing the Periphery (Leiden: Brill, 2015).

5 The interwar marketing and appropriation of Swedish design in the United States has been studied by Jeff Werner, Medelvägens estetik. Sverigebilder $i$ USA, del 1 (Hedemora: Gidlund, 2008), 241-342.

6 The government-initiated Swedish Institute for Cultural Exchange with Foreign Countries was founded in January 1945. See Nikolas Glover, National Relations: Public Diplomacy, National Identity and the Swedish Institute, 1945-1970 (Lund: Nordic Academic Press, 2011).

7 E.g. Zsolt Nagy, Great Expectations and Interwar Realities: Hungarian Cultural Diplomacy, 1918-1941 (Budapest: Central European University Press, 2017); Benjamin G. Martin, The Nazi-Fascist New Order for European Culture (Cambridge, Massachusetts: Harvard University Press, 2016).

${ }^{8}$ Louis Clerc and Nikolas Glover, 'Representing the Small States of Northern Europe: Between Imagined and Imaged Communities', in Clerc, Glover and Jordan, Histories of Public Diplomacy and Nation Branding.

9 See, for example, Peter Stadius, 'Happy Countries: Appraisals of Interwar Nordic Societies', in Peter Stadius and Jonas Harvard, eds., Communicating the North: Media Structures and Images in the Making of the Nordic Region (Farnham and Burlington: Ashgate, 2013); Kazimierz Musiał, Roots of the Scandinavian Model: Images of Progress in the Era of Modernisation (Baden-Baden: Nomos-Verlag, 2002); Carl Marklund and Klaus Petersen, 'Return to Sender: American Images of the Nordic Welfare States and Nordic Welfare State Branding', European Journal of Scandinavian Studies, 43, 2 (2013); Kiran Klaus Patel, 'How America Discovered Sweden: Reinventing Democracy during the 1930s', in Paul Nolte, ed., Transatlantic Democracy in the Twentieth Century: Transfer and Transformation (Berlin: Walter De Gruyter, 2016); Byron Rom-Jensen, 'A Model of Social Security? The Political Usage of Scandinavia in Roosevelt's New Deal', Scandinavian Journal of History, 42, 4 (2017), 363-88; Andreas Mørkved Hellenes, Fabricating Sweden: Studies in Swedish Public Diplomacy in France from the 1930s to the 1990s, PhD thesis, Sciences Po Paris \& University of Oslo, 2019, see especially chapter 1, 51-80.

10 Marquis W. Childs, Sweden. The Middle Way (New Haven: Yale University Press, 1936); Émile Schreiber, Heureux scandinaves! Enquête sur les réalisations socialistes au Danemark, en Finlande, Suède et Norvège (Paris: Denoël \& Steele, 1936). 
placed Sweden on the international 'mental map of the welfare state'. ${ }^{11}$ In France, where the socialist-led Popular Front had come to power in spring 1936, Schreiber's book signalled the breakthrough of a new set of tropes about Sweden, a country that was hailed as 'the happiest' in the world. ${ }^{12}$ This surge of foreign attention certainly did not go unnoticed in Sweden. The process of planning and producing the pavilions in Paris and New York offers an insight into how it emboldened Swedish elite circles, prompting them to explore novel diplomatic channels that allowed Sweden to make the most of its newfound position of (relative) influence.

The pavilions were the expression of a conscious broadening and popularising of Swedish statesponsored cultural diplomacy. Indeed, the dual crises of capitalism and democracy in the 1930s prompted feverish international activity among journalists, policy makers and social reformists across the globe. They studied policy developments abroad, debated what lessons might be learned from them and argued over what should be adopted in their respective home countries. ${ }^{13}$ The Great Depression did not just 'unmake and re-establish global links', it also 'synchronized debates and even the political and societal answers given to them'. ${ }^{14}$ These debates created a demand for accessible, up-to-date information about distant countries. They were fuelled by international flows of observers and reporters examining the standard of life, working conditions and day-to-day economic realities of foreign peoples. It was the experience of this on-going process that prompted the Swedish Arts and Crafts Society to identify a window of opportunity and advocate a Swedish 'offensive' at the world's fairs. The prospect of combining the marketing of consumer products with the presentation of social policies compelled the government to increase its support for this type of popular cultural diplomacy.

The government's newfound willingness to allocate these resources was facilitated by the fact that in the late 1930s the range of objectives that the pavilions aimed to achieve - commercial sales promotion, educating the public and projecting the nation abroad - could all be labelled advertising (reklam). ${ }^{15}$ This attracted industrialists, economists, architects, art historians, journalists and politicians to form a network, financially backed by the government, which took on the responsibility of producing comprehensive representations of their nation at the world's fairs. In this context, claiming to represent the expertise of 'the adman' (reklammannen), became a common rhetorical device within the network as members sought to gain influence, prescribe official action and secure public funds. ${ }^{16}$ From an international history perspective then, this study of Swedish fair participation during the 1930s adds to the increasingly entwined historiography in European countries of diplomatic activities and advertising culture. ${ }^{17}$ This research illustrates how self-appointed experts of promotional communication around Europe were keenly aware of the possibilities that popular culture and the mass media offered for promoting the national interest. Many of these experts did not hold formal, elevated positions in the state nor did they come from established commercial or cultural elites. Yet by claiming a professional knowledge that was 'part (social) technology part (social) science', the expanding advertising industry could use that platform to exercise great influence over how nation states pursued their interests abroad. ${ }^{18}$

The tendency to refer to advertising as something of a panacea was not unique to Sweden. As in other European countries at this time, 'advertising' was an amorphous concept which encompassed a

11 Kiran Klaus Patel, The New Deal: A Global History (Princeton: Princeton University Press, 2016), 228.

12 Schreiber, Heureux Scandinaves!, 148.

13 Patel, The New Deal.

14 Ibid., 43.

15 See, for instance, the advertisement for agency Ervaco (led by Folke Stenbeck), in Affärsekonomi, 20 (1937), 1181.

16 On the 'admen' and their disparate professional backgrounds, see Elin Gardeström, Reklam och propaganda under svenskt 1930-tal (Huddinge: Södertörn Academic Studies, 2018), 70-5.

17 See, for example, Scott Anthony, Public Relations and the Making of Modern Britain: Stephen Tallents and the Birth of a Progressive Media Profession (Manchester: Manchester University Press, 2012); Clerc, Glover and Jordan, Histories of Public Diplomacy and Nation Branding; Carolin Viktorin, Jessica C. E. Gienow-Hecht, Annika Estner and Marcel K. Will, eds., Nation Branding in Modern History (New York: Berghahn, 2018).

18 Oliver Kühschelm, 'Promoting the Nation in Austria and Switzerland', in Ulrich Ermann und Klaus-Jürgen Hermanik, eds., Branding the Nation, the Place, the Product (New York: Routledge, 2018), 149. 
range of practices that would later be separated: marketing, public relations, government information and political campaigns. Indeed, advertising was commonly framed as a form of social engineering. ${ }^{19}$ Precisely for that reason the Swedish case dealt with here underlines a point of broader relevance: the growing influence of advertising techniques in the 1930s should not be interpreted as a purely commercial practice that somehow invaded political and cultural spheres. Instead it evolved within and across such social and professional boundaries. Socially progressive organisations such as the Swedish Arts and Crafts Society, for instance, were by their very nature also in the business of deploying state-of-the art advertising techniques and public relations. Founded in 1845, the society originally strove to support traditional handicrafts in Sweden, but in the twentieth century turned increasingly towards the promotion of higher manufacturing and aesthetic standards to help Swedish products compete with cheap, industrially manufactured products. In the interwar years the society came to spearhead the introduction of modern artful yet rational production methods, seen as beneficial not only to aesthetic and economic development but also Sweden's social progress. ${ }^{20}$ In other words, selling the products, promoting the political values they represented and educating consumers about the modern lifestyle they were designed for were all inherent in the society's mission. And the society was by no means alone in linking social progress with the expansion of promotional culture. 'Advertising serves society', the Swedish Advertising Federation confidently proclaimed, and Social Democratic Prime Minister Per Albin Hansson publicly agreed. ${ }^{21}$ The prominent use of advertising practices in the diplomatic context of world's fairs hence articulated a pronounced trait of Sweden's domestic public culture and the social reformist agenda that dominated it.

By focusing on the central role ascribed to 'modern advertising' in the formation of interwar cultural diplomacy and how it grew out of domestic political and social processes, we also contribute to the literature on the world's fairs. In the 1930s the fairs underwent a distinct shift in character which was fully realised in the Paris exposition in 1937. Where once 'the expositions paraded fetish commodities and consumerism as an aesthetic event, the Exposition internationale of 1937 bore witness to the aestheticisation of politics and the fetishization of the nation' ${ }^{22}$ In Paris, for the first time all national exhibits were assembled within designated national pavilions. ${ }^{23}$ Historians have stressed that these comprehensive national projections - often explicitly ideological - came to represent alternative, competing models of modernity. The most flagrant examples were the state-approved architectural staging of Nazi Germany and the Soviet Union in Paris 1937, with their juxtaposed towering pavilions. ${ }^{24}$ But what about the small European states dwarfed by the powers jostling for global dominance? Acutely aware of their financial constraints and peripheral position, those in charge of their pavilions had to find other ways to attract attention. By dealing with an example of how this challenge was addressed the present study contributes a perspective from the margins of the world's fairs during the interwar period. The committees that produced the Swedish pavilion opted for a type of pavilion that presented Sweden as a compelling alternative to the bombastic boastfulness of the major powers. Against the background of looming global crisis, hitting the right note of strategic humility and well-presented sober matter-of-factness could in fact become

\footnotetext{
19 Stefan Schwarzkopf, 'What Was Advertising? The Invention, Rise, Demise, and Disappearance of Advertising Concepts in Nineteenth-and Twentieth-Century Europe and America', Business and Economic History Online, 7 (2009), 10-4.

20 Kåberg, 'An Introduction', 59-60.

21 Gardeström, Reklam och propaganda, 77. Hansson's position was not uncontroversial as there was widespread criticism of advertising within the labour movement, see Ibid., chapter 4. See also Erik Lakomaa, 'Advertising for the People: the History of the Social Democratic Party of Sweden's Own Advertising Company - Folkreklam and Förenade ARE-Bolagen, 1947-1997', Enterprise \& Society (2020).

22 Kate Kangaslahti, 'Absence/Presence: The Efficacity of Text, Image, and Space at the 1937 Exposition Internationale', Avant-Garde Critical Studies, 26 (2011), 192.

23 Robert H. Kargon, Karen Fiss, Morris Low and Arthur P. Molella, 'Introduction: World's Fairs, Modernity, and the Demand for Authenticity', in Robert H. Kargon, Karen Fiss, Morris Low and Arthur P. Molella, eds., World's Fairs on the Eve of War: Science, Technology, and Modernity, 1937-1942 (Pittsburgh: University of Pittsburgh Press, 2015), 4.

24 Marco Duranti, 'Utopia, Nostalgia and World War at the 1939-1940 New York's World's Fair', Journal of Contemporary History, 41, 4 (2008), 668.
} 
an attraction in its own right. ${ }^{25}$ 'Sweden's own understatement of her pavilion', one reviewer claimed in 1939, was 'refreshingly naïve'. 'It set forth facts' without 'the slightest suggestion of superiority'. ${ }^{26}$ With this approach the pavilions in 1937 and 1939 positioned Sweden as a locus for international deliberations about the social promises and challenges of modernity.

The findings are a result of extensive research in the archives of the organising committees of the three pavilions and in the archives of the Swedish Arts and Crafts Society. Material has also been located in the archives of the Swedish embassies in Paris and Washington and in the archives of the General Export Association. Moreover, we draw on articles and reviews published in advertising trade journals and daily newspapers in Sweden, France and the United States. We begin by contextualising the place of public exhibitions in domestic Swedish political culture, arguing that it was in Paris 1937 that this experience was first adapted for the national pavilion at a world's fair. We then analyse this process in more detail, showing how the Paris pavilion was conceived in reaction to what had (not) been done in Brussels, and how, in turn, the New York pavilion was determined by the experience of Paris. Finally, we proceed to focus on the ways in which the pavilions articulated ideals and practices of modern advertising, concentrating on the relationship between democratic propaganda as a social-reformist project and as national positioning.

\section{Exhibitions: A Proven Means for Influencing the Public}

The Swedish pavilions in Paris and New York featured a mode of public exhibiting transplanted from the fledgling welfare state to the international context of world's fairs. At the Stockholm Exhibition in 1930, an initiative of the Swedish Arts and Crafts Society, adverts and advertising professionals played a key role in the overall ambition to promote functionalist architecture, 'modern living' and contemporary decorative arts. The exhibition received a great deal of attention abroad and showed the potential of the medium of public exhibitions (utstälningar) for addressing domestic citizens-cum-consumers. ${ }^{27}$ In the years following that successful event advertising professionals increasingly managed to establish themselves as indispensable experts in this domestic field of public communication. They laid claim to the specialist knowledge of what has been termed 'politicodidactics': 'efforts to make social-scientific concepts, ways of knowing, and representations a public matter. ${ }^{28}$ 'Admen' successfully promoted the notion that they provided the necessary state-of-the-art skills when it came to designing informative public displays and capturing visitors' attention. Several exhibitions in 1930s Sweden on social issues sought to influence popular attitudes by means of prompting self-reflection and instigating discussions amongst members of the public. ${ }^{29}$ This use of exhibitions in Sweden during these years has been dubbed social-reformist 'democracy activism', aimed at both educating and entertaining citizens. ${ }^{30}$

Given the advertising industries' expanding social domain, it was only a matter of time before its cadre of experts turned their attention to Sweden's official self projections abroad. In the mid-1930s they saw their opportunity as the government increased its spending on information about Sweden

\footnotetext{
25 See Greg Castillo, 'Making a Spectacle of Restraint: The Deutschland Pavilion at the 1958 Brussels Exposition', Journal of Contemporary History, 47, 1 (2012). A similar approach was attempted, seemingly with less success, in the joint Nordic pavilion in Osaka 1970. See Nikolas Glover, 'Unity Exposed: The Scandinavia Pavilions at the World Exhibitions in 1967 and 1970' in Harvard and Stadius, Communicating the North, 219-39.

26 Henry Beckett, The New York Post, 18 May 1939. Cited under 'American Comment' in Naboth Hedin, ed., Sweden at the New York World's Fair (1939).

27 Gardeström, Reklam och propaganda, 27-56; Ylva Habel, Modern Media, Modern Audiences: Mass Media and Social Engineering in the 1930s Swedish Welfare State (Stockholm: Aura, 2002).

28 Frans Lundgren, 'Making Society a Public Matter: A Cultural History of the Social Sciences' Politico-Didactics', in Rickard Danell, Anna Larsson and Per Wisselgren, eds., Social Science in Context: Historical, Sociological and Global Perspectives (Lund: Nordic Academic Press, 2013), 64.

29 Petter Tistedt, Visioner om medborgerliga publiker: Medier och socialreformism på 1930-talet (Höör: Brutus Östlings Bokförlag Symposion, 2013).

30 Ibid., 255-9.
} 
abroad. Funds were channelled to the press division of the Ministry for Foreign Affairs. Some of these additional resources were used to fund press attachés and to support Sweden's foreign lecturer program and international intellectual exchanges. ${ }^{31}$

However, for those promoting the broader social relevance of the advertising profession, including many of the prominent figures in the Arts and Crafts Society, resorting to scholars and bureaucrats simply did not suffice. According to leading advertisers in a debate about the government's new cultural diplomacy efforts, the government had to enlist them or Sweden would inevitably find itself presenting 'the face of an old man' to the world. ${ }^{32}$ Only with the help of modern advertising techniques, they argued, would Sweden be able to address and engage broader publics. As Table 1 shows, this claim convinced the government. In a development hitherto overlooked by historians, public spending on the world fairs increased steeply from 1935 to 1939, and so did the state's share of the total cost of participation. As compared to the budget of the Ministry for Foreign Affairs' information work abroad and its press attachés, the funds set aside for the pavilions are quite remarkable. From being roughly equivalent in 1935, spending on pavilions grew to be over four times larger than the information and press budget in 1937 and six times larger in 1939. This marked a new era in Swedish state-sponsored cultural relations: the government officially recognised the value of national participation in popular international events such as world exhibitions. Here, as in the domestic public sphere, proponents of modern advertising thereby advanced their positions.

The government's increasing willingness to spend money on fair participation was inversely related to the major Swedish industries' decreasing willingness to contribute. Although they were in favour of a Swedish pavilion, they saw little incentive in exhibiting their wares in pavilions that were so explicitly sociopolitical, and the income from corporate sponsors consequently decreased markedly between 1935 and $1937 .^{33}$ Following the general trend at the fairs, then, the logic of Swedish participation migrated from primarily commercial to essentially political. The process can be summarised with the help of the genre distinctions used by the advertisers themselves: Swedish participation shifted from what was described as an 'industry exhibition' (industriutställning) in Brussels aimed primarily at selling products, via a 'social exhibition' (socialutställning) in Paris aiming to comprehensively visualise contemporary Swedish society to an 'idea exhibition' (idéutställning) for New York, intent on engaging the public and sparking its interest in contemporary Sweden. As we shall see, the difference between the latter two pavilions was not necessarily discernible beyond professional circles since both exhibits combined works of art, product displays, advertising aesthetics, information plaques and visual politico-didactics. Nonetheless, there was a de facto shift in emphasis between 1937 and 1939. The exhibit in Paris sought to systematically explain how Sweden worked, while the organising principle of the New York pavilion was an explicit idea: to show how Sweden adhered to the fair's official theme of 'building the world of tomorrow. ${ }^{34}$

\section{Brussels to Paris: From Industrial Showroom to Social Exhibit}

Open for just over six months, the World's Fair in Brussels in 1935 was visited by around twenty million visitors, and thirty nations participated. The Swedish pavilion in Brussels, encompassing 1,000 square metres, was essentially conceived of as a means to display the country's main industry and agriculture, its products and its trademarks. Ahead of the exhibition indications that the Danish pavilion was particularly ambitious spurred the Swedish committee and its public and private sponsors to expand its initially quite modest plans. ${ }^{35}$ In effect, Sweden's General Export Association (Sveriges

31 See, for example, Prop. 1 1936/37, 'Tredje huvudtiteln', 32-3. Åkerlund, Mellan akademi och kulturpolitik, 135-42.

32 'Vårt lands ansikte är gammalmans', Svenska Dagbladet, 12 Dec. 1936; 'Vårt ansikte utåt', Reklamnyheterna, 20 Dec. 1936.

33 See, for example, 'New York-utredningens betänkande', 17 Jan. 1938, Series F1c, Vol. 326, Beskickningsarkiv Washington (BW), Riksarkivet (RA), Stockholm, 6-8.

34 'New York-utredningens betänkande', 17 Jan. 1938, Series F1c, Vol. 326, BW, RA, 16-7.

35 'Protokoll vid sammanträde den 3 oktober 1934 med bestyrelsen för Sveriges deltagande i Brysselutställningen 1935', Vol. 1, Utställningsbestyrelserna (U12), RA. 
Table 1. The Swedish world's fair pavilions in 1935, 1937 and 1939. Cost comparison (SEK) and funding breakdown

\begin{tabular}{llll}
\hline & 1935 & 1937 & 1939 \\
\hline $\begin{array}{l}\text { Ministry for Foreign Affairs' regular budget for general information about } \\
\text { Sweden and press attachés* }\end{array}$ & 110000 & 128000 & 202100 \\
\hline Fair participation, total cost & $600000^{\mathrm{A}}$ & $820846^{\mathrm{B}}$ & $1645000^{\mathrm{C}}$ \\
\hline Fair participation, state support & $150000^{\mathrm{A}}$ & $541253^{\mathrm{B}}$ & $1326930^{\mathrm{C}}$ \\
\hline Fair participation, state support, share of total cost & $25 \%$ & $65 \%$ & $80 \%$ \\
\hline $\begin{array}{l}\text { Ratio: Fair participation (state support)/regular budget for general } \\
\text { information }\end{array}$ & 1.3 & 4.2 & 6.5 \\
\hline
\end{tabular}

Sources

*Based on government bills Proposition 1, 1934-5; 1936-7; 1938-9. The sums include the posts Upplysningsverksamhet om Sverige i utlandet and in 1937 and 1939 also Pressattachéer. Until the budgetary year 1935-6 the pressattachés were included in the post Upplysningsverksamhet.

${ }^{A}$ Prytz \& Sachs, Till chefen för Kungl. Handelsdepartementet, 16 June 1936, 4-5. Vol 1, U12, RA.

BEriksson, 'Revisionsberättelse', attachment to Slutberättelse till Kungl. Handelsdepartementet och Kommerskollegium (undated draft). Vol. 83, Series F2, SGEA, RA.

'The government reserved 1400000 SEK, but the whole sum was not used. 'Ekonomisk redogörelse' in Bernadotte, Generalkommissariens slutapport (undated draft). Vol 3, SNYU-1939, RA.

Allmänna Exportförening; SGEA), a private organisation, was in charge of the entire endeavour. Participating firms and industry organisations paid for their space and participated in their allotted square metres with their own exhibits and advertising materials. ${ }^{36}$ The pavilion also contained some limited displays that presented the main sectors of the Swedish economy, collectively sponsored by trade associations such as the Swedish Timber Export Association (Svenska trävaruexportföreningen), the Swedish Cellulose Association (Svenska cellulosa föreningen) and the Paper Mill Association (Svenska pappersbruksföreningen). ${ }^{37}$ An introductory area immediately inside the entrance, made up of large-scale photographic montages produced by the advertising pioneer Harald Rosenberg, presented Sweden as a tourist destination. In one corner a sandwich bar sold items intended to show off the high standard of Swedish agrarian produce. Elsewhere at the fair, Swedish contributions were displayed outside the national pavilion. Fine arts were exhibited separately in the building dedicated to international art, and the Swedish state-owned railway company participated in the international transport and communications hall.

After the fair closed in November 1935 the final report of the Swedish committee - surveying the latest exhibition trends on the grounds - acknowledged that a traditional commercial showcase of the type Sweden had supplied was rapidly becoming obsolete. The committee lamented the firm-centred approach. It highlighted the outdated character of many of the individual companies' exhibits and underlined the need for better coordination, as well as a unifying vision for the pavilion. Rosenberg had attempted in vain to convince participating firms to adhere to a common graphic profile when producing their signs, arguing that each display should be designed to take the shared exhibition space into account. Several of them simply refused, pointing out that they had paid for their section of the pavilion and were thus free to promote themselves as they saw fit. ${ }^{38}$ The final report also noted the relative lack of space dedicated to decorative arts, which had the unfortunate consequence that the Danish exhibits in this area overshadowed the Swedish ones. Not only that, the Danish pavilion's elaborate presentation of Denmark as a country and society was held forth as an example worth following. The concluding evaluation therefore recommended including a broader presentation of Swedish

36 'Sverige på Brysselutställningen', Svensk Export, 9 Feb. 1935, 29-30; 'Protokoll vid sammanträde den 23 juli 1934 vid konstituerande sammanträde med bestyrelsen för Sveriges deltagande i utställningen i Bryssel 1935', Vol. 1, U12, RA.

37 'Protokoll vid sammanträde den 23 november 1934 med Bestyrelsen för Sveriges deltagande i Brysselutställningen 1935', Vol. 1, U12, RA.

38 'Protokoll vid sammanträde den 13 februari 1935 med Bestyrelsen för Sveriges deltagande i Brysselutställningen 1935', Vol. 1, U12, RA. 
society in the future. Sweden's 'advanced position' in the cultural and social domain would make such a segment interesting for pavilion visitors and would be 'good propaganda for Sweden'. ${ }^{39}$

The following year these recommendations were incorporated into the early plans for participation in Paris. This meant that the main responsibility for organising the pavilion shifted from the SGEA, which expressed little interest in working with a pavilion that was not concerned with marketing export products, to the Arts and Crafts Society that instead saw an opportunity to transfer its visions of social and aesthetic reform to a receptive international public. The Society seized on the general lack of enthusiasm about the Brussels pavilion and turned it to its own advantage, petitioning the government with the 1936 call for a Swedish offensive in Paris with which this article opened. As no other organisation asserted any rival claims to the project, the Society was in effect authorised by the government to take charge of Sweden's official participation. The Society's periodical Form announced enthusiastically that at the world's fair in Paris all Swedish exhibits would be concentrated within a single national pavilion for the first time. ${ }^{40}$ The Society defined two goals for Swedish participation: Sweden's self-projection was to both introduce and establish Sweden as a country dynamically seeking to build a better society for its people, and it was to defend Sweden's position as a world leader within decorative arts. This field was 'the best propaganda as value measure for a country's cultural level,' as the Brussels evaluation had pointed out. ${ }^{41}$ In Paris, the Society argued, Sweden should fuse the two in a 'social exhibition' that combined the advanced character of Swedish social policies with the high quality of the country's decorative arts. ${ }^{42}$

Most of the Arts and Crafts Society's ideas were taken over by the government-appointed Official Committee that in March 1936 began planning Sweden's participation in Paris. The preparatory work in drawing up the texts for the social section was undertaken by no lesser authorities than the Social Democratic economist and politician Gunnar Myrdal and Mauritz Bonow of Sweden's powerful Co-operative Union (Kooperativa förbundet; KF). ${ }^{43}$ The final product was eventually produced by the pavilion architect Sven Ivar Lind with the help of a group of young architects subscribing to the social reformist tenets of the functionalist movement. The result was a pavilion that, in a way hitherto unrivalled in Swedish exhibition history, entered political territory, showcasing Sweden above all as an example of social and democratic progress. ${ }^{44}$ Compared to Brussels, the size of the Swedish pavilion had expanded by 50 per cent, to 1,500 square metres. Of the Paris Expo's thirty-one million visitors, the Swedish pavilion on the bank of the Seine saw daily numbers of around 25,000-30,000. ${ }^{45}$ The message it conveyed was stated immediately on entering the pavilion, where a programmatic declaration proclaimed 'On peace and universal cooperation we Swedes depend. The aim of our country is: Liberty of thought, Democracy, Unity'. ${ }^{46}$

Whereas the main hall of the Swedish pavilion in Brussels in 1935 had been filled with displays showcasing the main industrial companies, such exhibits were replaced in the Paris pavilion by two large artworks sponsored by two of the mightiest pillars of social democratic Sweden - the National Confederation of Trade Unions (Landsorganisationen; LO) and the Co-operative Union offering allegorical interpretations of Sweden and Sweden's role in the modern world. The pavilion's clou was the social section, where Lind and his team mixed elements from old and new exhibition practices. Although playful elements were not entirely absent, the didactics used to present

\footnotetext{
39 Ljungberger, 'Sveriges deltagande i världsutställningen i Bryssel. Några iakttagelser', 7 Jan. 1936, Vol. 1, U12, RA, 8.

40 Sven Ivar Lind, 'Vår paviljong på Parisutställningen 1937', Form, 33, 1 (1937), 1.

41 Ljungberger, 'Sveriges deltagande', 7 Jan. 1936, Vol. 1, U12, RA, 7.

42 Hald and Stavenow to Kommerskollegium, 7 Jan. 1936, Series F1, Vol. 9, SvF, CfN, 2-4.

43 On the role of KF in the construction of Sweden as a 'middle way' see Mary Hilson, 'Consumer Co-operation and Economic Crisis: The 1936 Roosevelt Inquiry on Co-operative Enterprise and the Emergence of the Nordic "Middle Way"', Contemporary European History, 22, 2 (2013).

44 For more on the production and reception of the pavilion see Mørkved Hellenes, Fabricating Sweden, 81-168.

45 Sachs, Sohlman and Peyron to Kommerskollegium, 'Slutberättelse till Kungl. Handelsdepartementet och Kommerskollegium', Nov. 4 1939, Series F2, Vol. 83, Sveriges Allmänna Exportförenings arkiv (SGEA), RA, 9.

46 Åke Stavenow, ed., International Exhibition Paris 1937: Sweden. Guide-Book (1937), 12.
} 
Sweden's natural and economic geography resembled the visual statistics of experimental interwar social museums. ${ }^{47}$ This was evident in the presentations of the four main industries of Sweden - agriculture, forestry, mining and hydropower - here presented as 'the groundwork of social economic life. ${ }^{48}$ Lind himself stated in a presentation of the social section that there were no commercial ambitions and limited advertising in this part of the exhibition. ${ }^{49}$ As such, it was indicative of the Swedish exhibiters' attempts to apply techniques of advertising to create an exhibition where individual firms were not placed centre stage. The displays were conceived to inform visitors about a collective: Sweden as a country. Its industries were exhibited as natural and social facts rather than through separate products or trademarks.

In this way, Sweden's Paris pavilion harked back to the reformist ethos of the Stockholm Exhibition in 1930. Its presentation of the nation as a whole included topics that within Sweden were subjects of intense political debate, such as the Social Democrats' expansionist welfare politics. In Paris, however, such domestic strife was conspicuously absent. Next to a segment of the display dedicated to explaining how Sweden had overcome the depression, a large sign announced that 'in Sweden we seek to solve the difficulties of the day by social reforms. ${ }^{50}$

With the prevalence of the words 'we' and 'our' in the pavilion's texts, the exhibit took the position of speaking on behalf of the entire Swedish people. Conversely, there were very few named or recognisable individuals in the Swedish exhibition. Instead, the social section focused on the anonymous masses of Swedes, ordinary workers who were depicted through photomontages showing them at work, in study circles or enjoying the benefits of modern social housing. This national 'we' echoed the pavilion's motto 'The Swedish People United in Work'. ${ }^{51}$ Inspired by the idea that the façade towards the Seine river during the exhibition season was one of the world's prime advertisement spots, Lind's intention was to put up a four metre tall electrically illuminated tube light sign, with the word 'Sweden' (Suède) followed by the pavilion motto, but due to rising costs the idea was abandoned. ${ }^{52}$ Nevertheless, in sum the Swedish pavilion in Paris, with its slogan-like political statements, along with the nature of the exhibits, contributed to a national projection that presented Sweden as having solved the economic crisis by democratic means, thus offering an alternative message to the fairs' totalitarian participants. Reviews in the French press, to which we return below, soon revealed that this was at least how many French visitors enthusiastically perceived it.

Despite the praise in the French press, the pavilion came under furious fire from within Sweden, primarily in the bourgeois press. While the criticism had political undertones, it centred above all on the architecture of the pavilion - it was frequently ridiculed as a 'packing crate' - and the design of the exhibition. ${ }^{53}$ From the start the committee had sought to strike a balance between commercial and political communicative ideals, but this proved difficult to uphold. For all their authors' intellectual and political clout, Gunnar Myrdal and Mauritz Bonow's early drafts were considered far too centred on content and oblivious to the exhibitory form by the designers and advertisers on the committee. Heated discussions followed amongst the members, in effect concerning whether advertisers or social scientists had the ultimate say on what constituted professional politico-didactics. This led to the resignation of key figures on either side of the debate: on the one hand the economist Bonow, on the

\footnotetext{
47 On social museums, see Frans Lundgren, Mediating the Welfare State: Social Museums, Documentary Films and the Education of the Public (Uppsala: Uppsala University, 2012).

48 Stavenow, International Exhibition Paris 1937, 15.

49 Sven Ivar Lind, 'Utställningstekniska anordningar i vår Paris-paviljong’, Byggmästaren, 16, 32 (1937), 358.

50 Svea Lindstrand, 'Glimtar från en världsutställnings tillblivelse’, Form, 33, 6 (1937), 149.

51 Lind, 'Utställningstekniska anordningar i vår Paris-paviljong', 357.

52 Ibid.; Colomba, 'Paviljongarkitekten: Vi hade inte pengar . . . ', Dagens Nyheter, 29 June 1937.

53 'Varför inte litet fantasi? En torr och pedantisk utställare är "lyckliga Sverige" i Paris', Aftonbladet, 8 June 1937; Mars, 'Isaac: "Svenska packlåren i Paris". Vår paviljong har gjort fiasko', Aftonbladet, 27 June 1937; Eva von Zweigbergk, 'Kavaj på galafest. Sverige på Expo', Dagens Nyheter, 2 July 1937; Ven Nyberg, 'Svenskar och andra utlänningar på Expo', Svenska Dagbladet, 15 July 1937.
} 
other 'adman' and cultural critic Gotthard Johansson. ${ }^{54}$ Stockholm broadsheet Svenska Dagbladet warned that the muddled social exhibition threatened to undermine the entire Swedish exhibit:

Now, with less than half a year left before the opening of the Paris Exposition, it looks . . . like Sweden's participation is in danger of becoming a comical fiasco in the (self-) important, doctoral economists' style, with swathes of sociologically enlightening statistics, curling themselves in beautiful neon loops, but with very few attractive adornments for the public. ${ }^{55}$

The critics considered their fears warranted when the pavilion opened in June, and the entire exhibit was consistently criticised throughout the summer in the Swedish media. It was attacked for its stern focus on socio-political facts, its supposed lack of coherence and its absence of festive elements. Despite Lind's conscious efforts to renew the genre of national pavilions, he had simply not gone far enough in his use of modern advertising. ${ }^{56}$ In July an entire issue of the advertising trade journal Advertising News (Reklamnyheterna) was largely devoted to criticising the pavilion. Written by the journal's editor-in-chief Gustaf Rosenberg (no relation to Harald), the editorial derided the pavilion as a 'scandal'. ${ }^{57}$ According to him, 'exhibiting is advertising,' meaning that all the various elements of a pavilion had to be placed in the service of that essential premise. This was far from easy and 'could not be left to architects alone'. ${ }^{58}$

\section{Paris to New York: From Political Alternative to Popular Attraction}

While the pavilion in Paris was still being debated work began on planning Sweden's participation in the 1939 World Fair in New York. In mid-August 1937 the Ministry of Trade appointed a preparatory committee to consider whether and how Sweden should participate. It is clear that the persistent criticism from Swedish advertisers about the Paris pavilion had had the desired effect, as the New York committee from this time onward treated the entire project as an advertising brief. It quite precisely followed an approach that Harald Rosenberg had advocated in a public debate in late 1936:

How would an adman, if presented with such a task, go about planning its solution? As in the planning of all other advertising, he would first conduct comprehensive market research... The market is the exhibition's [prospective] visitors. On behalf of what goods and ideas is the propaganda to be conducted? When that question is answered, a programme is drawn up that captures the idea of the exhibit. The plan specifies what spaces are required for the various details, what goods are necessary and the presentation of texts and images. ${ }^{59}$

Rosenberg placed 'the adman' and his market research at the centre of the whole project, and so did the preparatory New York committee. It began by seeking to ascertain in which Swedish 'conditions and phenomena' US publics were most interested. Among its members, the committee counted Folke Stenbeck, head of Ervaco, one of Sweden's leading advertising executives, and the Chairman of the Swedish Advertising Federation. Along with the Director of the SGEA and professor Gerhard Törnqvist at the Stockholm School of Economics, Stenbeck formed a special market research committee. Stenbeck's and Törnqvist's own market research company IMU (Institutet för marknadsundersökning) took on the task of conducting the committee's exploratory research. In collaboration with Ervaco's owners, the New York-based agency Erwin \& Wasey Co., surveys soon went

\footnotetext{
54 Hellenes, Fabricating, 102-3.

55 'Ystad duger i Newyork 1939 - ej i Paris i år', Svenska Dagbladet, 5 Jan. 1937.

56 E.g. 'Varför inte litet fantasi? En torr och pedantisk utställare är "lyckliga Sverige" i Paris', Aftonbladet, 8 June 1937.

57 Gustaf Rosenberg, 'Sverigepaviljongen i Paris amatörmässig ur reklamsynpunkt', Reklamnyheterna, 16 July 1937.

58 Gustaf Rosenberg, 'Världsutställningar som reklam-och propagandamedel. Och frågan om Sveriges utställning i Paris', Reklamnyheterna, 16 July 1937.

59 Cited in 'Paviljongen är inte det första', Reklamnyheterna, 30 Dec. 1936.
} 
out to the subscribers of the Swedish Chamber of Commerce's American-Swedish Monthly, to former transatlantic ferry passengers of the Swedish America Line in New York, to subscribers to Swedish-American newspapers and to a select group of Swedish citizens. An in-depth interview survey with US 'exhibition specialists' was also conducted. ${ }^{60}$

The results of the market research, amply referred to in the preparatory committee's final report, strengthened the hand of the advertising contingent in the planning process. The themes that American respondents found particularly interesting were those associated with socio-political issues, among them the fight against unemployment, overcoming the depression and providing a universal pension system. 'It is their own American problems the respondents are recognising here', IMU declared. ${ }^{61}$ According to the IMU's report, American exhibition specialists stressed that whatever the themes, the presentation had to use modern advertising techniques, it had to be easy to understand 'and the aspect of entertainment should not be overlooked'. ${ }^{62}$ The US experts thus advised the Swedes to use their plot at the fair strategically: to create a space for relaxation and entertainment, a good meeting spot, with toilets, a fine restaurant and places to rest tired legs. Fundamentally, they declared, it was less important what was chosen for the display than how it was displayed. ${ }^{63}$

Having decided to proceed with the plan to participate with a national pavilion in the New York World's Fair, the government officially appointed a Royal Committee in March 1938 and a Commissioner General, Count Folke Bernadotte. The themes raised in the initial market research and its emphasis on ensuring a light touch remained. The committee stipulated that the pavilion must be given 'a shimmer of romance', that the 'human aspect' had to be emphasised, that it not include 'too many statistics or photomontages' and that it should be characterised by 'comfort and rest'. ${ }^{64}$ This strategy of using the pavilion to offer visitors something of a refuge from the other exhibits was one of the reasons why it later was deemed such a success in both the Swedish and US press. ${ }^{65}$ Working with the motto 'Sweden - Built in Freedom', the exhibits were structured around the fair's official theme 'building the world of tomorrow'. ${ }^{66}$ The ambition to project Swedish social reforms was retained from Paris, but the contents of these exhibits were less contentious this time around. By now, they were seen to be less exclusively Social Democratic and more inclusively national in character. This was underlined by the more prominent uses of Swedish flags, historical figures and cultural artefacts in New York as compared to Paris. The fact that the renowned liberal economist Bertil Ohlin was appointed as a consultant on the committee further served to depoliticise its character by including the political opposition to the Social Democrats.

Consequently, in contrast to 1937 the pavilion in 1939 was widely well received also within Sweden. The fair in New York was open for two seasons, in 1939 and 1940, but Sweden's official participation only lasted for the original first six-month period. Of the twenty-five million people who visited the grounds in 1939, the Swedish pavilion - this time on a plot three times the size of the one in Paris, 4,600 square metres - was visited by an estimated 20,000 people per day. ${ }^{67}$ The building was designed by the renowned Chief Architect Sven Markelius, who belonged to the same politically engaged circles as Sven Ivar Lind, and who had been involved in the Stockholm Exhibition in 1930. In order to keep construction costs down, the low building centred round a paved square with a pool, garden and dining area. In contrast to the anonymous groups of Swedes projected in Paris, the signature façade here

\footnotetext{
60 IMU, 'Till New York-utredningen: Rapport över undersökningar i U.S.A. och Sverige för Sveriges deltagande i The New York World's Fair 1939'. Vol. 1, U15, RA.

61 Ibid., 11

62 'New York-utredningens betänkande', 17 Jan. 1938, Series F1c, Vol. 326, BW, RA, 6.

63 IMU, 'Till New York-utredningen', 55. For more on the pavilion, see Werner, Medelvägens estetik, 313-38.

64 'Protokoll hållet vid Bestyrelsens för Svenska New York-utställningen 1939 sammanträde', 4 Apr. 1938. Vol. 1, Svenska New York-utställningens 1939 arkiv (SNYU-1939), RA.

65 E.g. 'Århundradets jättecirkus', Futurum, 3 (1939), 147; 'At the Fair', The Nation, 20 May 1939; 'Sweden', Svenska Dagbladet, 24 Apr. 1939; Åke Stavenow, 'Sverige på New York’s Fair', Form, 35, (1939), 122.

66 See e.g. 'New York-utredningens betänkande', 17 Jan. 1938, Series F1c, Vol. 326, BW, RA, 16-7; Bernadotte's introduction to Hedin, Sweden at the New York World's Fair.

67 'Generalkommissariens rapport angående svenska utställningen i New York' (draft version), Vol. 3, SNYU-1939, RA.
} 
was used to present individual Swedish people. Functioning as a billboard-like surface under the bold title 'Sweden speaks', the wall was covered with large advert-like portraits, among them Prime Minister Per Albin Hansson and a 'typical, blond-haired young Swedish couple'. ${ }^{68}$ Inside, in the decorative arts section, a series of home interiors complete with furniture and set tables displayed the decorative arts in their 'natural habitat'. Since 1937, when American reviewers of the Swedish pavilion in Paris had introduced the term 'Swedish modern' in their press reports, Swedish design had enjoyed increasing commercial success in the United States. ${ }^{69}$ This spontaneous brand was too good to forfeit, and the term 'Swedish modern' was embraced in the decorative arts section in New York by the Swedes themselves albeit with the corrective ambition of presenting 'Authentic Swedish Modern'. ${ }^{70}$ Abroad, the Swedish Arts and Crafts Movement explained, 'Swedish Modern' had come to be known as a style: 'something stationary and final'. In fact, it was a 'dynamic movement' which was constantly seeking new ways to attain a number of socio-political principles. ${ }^{71}$

In the adjacent social section, again in contrast to Paris, individual Swedes - scientists, specialists, politicians - were placed centre stage. Representing different dimensions of Sweden's on-going social reforms, each photographic poster of a prominent person displayed both a striking slogan and, in smaller print, a more informative 'story' (the English word was used in Swedish texts) about the broader social developments that the individual represented. 'Plenty of power to remove the drudgery', the section on hydropower announced. 'Less sickness through more prevention', the section on medical research declared. A cadre of English-speaking Swedes, trained to personally answer all the visitors' questions about the exhibit, were available around the pavilion. The use of technical gadgets was another novel feature in contrast to Paris. The quality of Swedish steel was illustrated by a long, thin sheet continuously being pulled by a magnet. Behind the 'tourist bar', a large map of Sweden on the wall showed various tourist regions. Visitors could pick up telephones, dial the regions' respective telephone numbers and listen to pre-recorded messages informing them about local attractions. In the pavilion's air-conditioned restaurant Three Crowns, which was used throughout the summer to attract celebrities and entertain prominent guests, Swedish specialities could be selected from a continuously revolving smorgasbord. ${ }^{72}$

Aside from the actual design and contents of the pavilion, the organisation surrounding it was also much more geared towards public relations and managing expectations. The appointment of the 'Propaganda Section' under the supervision of Stenbeck, alongside the subject-oriented working groups, secured the influence of this particular dimension of the advertisers' professional know-how. The issue of creating and handling publicity was ever-present in the committee's work, and the budget set aside for this was significant. ${ }^{73}$ It allowed for the employment of a press secretary in New York and a copywriter to assist him but also for a press officer in Stockholm to handle publicity matters on the home front. The main priority of the latter's work was to ensure that the pavilion in New York was not subjected to the same hostile press treatment as the one in Paris. ${ }^{74}$ As for reaching the US public, the press secretary and planning committee worked closely with the experienced Swedish-American News Exchange based in New York, and drew heavily on well-established contacts with the broader

\footnotetext{
68 Hedin, Sweden at the New York World's Fair, n.p.

69 Werner, Medelvägens estetik, 287-9.

70 Philip Gustafson, Sweden at the New York's World Fair, Series F1c, Vol. 324, BW, RA. Emphasis added. Similarly, the label 'the Middle Way' made so famous by Marquis Childs was applied in the leaflet's presentation of Sweden.

71 These included producing high quality goods for everyday use, fusing 'natural form and honest treatment of material' and creating 'aesthetically sound goods, resulting from the close cooperation of artist and manufacturer'. The Royal Swedish Commission, New York World's Fair 1939, Swedish Arts and Crafts: Swedish Modern - A Movement Towards Sanity in Design (Stockholm, 1939), 13.

72 Ibid.

73 In contrast, all official events at the Swedish pavilion in Brussels had been covered by private donations. 'Protokoll vid sammanträde den 21 januari 1935 med arbetsutskott inom Bestyrelsen för Sveriges deltagande i Brysselutställningen 1935', Vol. 1, U12, RA.

74 'Hur Sweden ska framträda på New York World Fair', Reklamnyheterna, 16 Dec. 1938.
} 
Swedish-American community. ${ }^{75}$ The Swedish Chamber of Commerce set up an Advisory Committee in New York, consisting of local Swedish-American business leaders, the Swedish Consul and the Ambassador. ${ }^{76}$

Even before the pavilion was officially inaugurated, the press officers began feeding the US press with stories from the Swedish pavilion; some considered important, others purely anecdotal. Throughout most of the summer a two-page bulletin with brief stories was produced within the Swedish camp and distributed on a daily basis, and this channel proved a very effective means for engaging news outlets. The press officer reported back to Stockholm that the bulletin 'has been enthusiastically received by the radio, magazine and newspaper people'. The resulting publicity had spread nationwide, 'through the syndicates and news agencies; one of our stories was used by 400 papers of America'. ${ }^{77}$ 'Even if you do not have to grovel before the press', the final report from New York acknowledged, it must be admitted that it is through the press that the general public receives its anticipatory impressions of the exhibition'. Therefore, the report concluded, the extensive care with which representatives of the press had been looked after in New York 'cannot be over emphasised'. ${ }^{78}$

\section{Staging Democratic Propaganda}

Around four million people visited the Swedish pavilions in 1937 and 1939, approximately 13 per cent of the visitors in Paris and 10 per cent of the New York Fair's 1939 season. ${ }^{79}$ Reports in the French and US press enthusiastically praised the attractive and informative way in which the pavilions provided millions of visitors presentations of modern Sweden - its social policies, economic realities and decorative arts. For newspapers of the conflict-ridden French left, the Swedish pavilion represented a successful example of the achievements of socialism in power. This view was taken in publications that supported the Popular Front but also in the anti-communist socialist press that had abandoned the coalition. The government mouthpiece Le Populaire stated that the social ambitions of Sweden were reflected in its decorative arts, which expressed the struggle to create a modern society 'where beauty would no longer be arbitrarily separated from utility'. ${ }^{80}$ One reviewer believed that 'every civilised man would bow [down] when faced with the lesson of stability, wisdom and measure' presented by the Swedes. ${ }^{81}$ Another glowingly reported about the lesson he had received from 'a country that, in the face of the nightmares of [today's] world, flaunts its joy over being free, ${ }^{82}$ In 1939 the New York Post's reporter lauded a pavilion that was 'delightfully serious and seriously delightful', praising 'the Swedish people' for having 'honoured us by assuming that the Fair really is what it pretends to be: an exposition of first importance, a concentration of choice examples of men's skill and ingenuity today, and a center for new ideas' ${ }^{83}$ Harper's Magazine found the social reforms 'superbly depicted', and the influential critic Douglas Haskell lyrically proclaimed that the 'Swedish pavilion is

75 For the background of the Swedish-American News Exchange, see Carl Marklund, 'A Swedish Norden or a Nordic Sweden: Image Politics in the West during the Cold War', in Harvard and Stadius, Communicating the North, 267. On the Swedish-American community's diplomatic efforts, see Adam Hjorthén, Cross-Border Commemorations: Celebrating Swedish Settlement in America (Amherst: University of Massachusetts Press, 2019), esp. chapter 6.

76 See, for example, 'P.M. on showing of Sweden's industry and trade at the New York World's fair 1939', 20 July 1938, Series F1c, Vol. 324, BW, RA.

77 Gustafson to Ericsson, letter dated 27 June 1939, Vol. 14, SNYU-1939, RA. See also Ericsson to Möller, letter dated 10 May 1939, Vol. 3, SNYU-1939, RA.

78 'Generalkommissariens rapport... .', 20.

79 Svenska slöjdföreningens årsberättelse 1937 (Uppsala: Almqvist \& Wiksell, 1938), 7; 'Generalkommissariens rapport ...', 13.

80 Jean-Maurice Herrmann, 'Promenades dans l'Exposition: Le Pavillon de la Suède socialiste', Le Populaire, 26 June 1937.

81 F. M. Calmont, 'Le pavillon de la Suède', La Flèche, 25 Sept. 1937.

82 Georges Altman, 'Arts et Techniques au service de la raison: A l'Exposition dans les Pays ou (sic) vit la liberté', Volonté. Hebdomadaire économique et politique, 20 Oct. 1937.

83 Henry Beckett in The New York Post, 18 May 1939, cited under 'American Comment' in Hedin, Sweden at the New York World's Fair, n.p. 
civilization! ${ }^{84}$ A month into the fair, the Swedish press officer reported that the pavilion and restaurant 'rank among the first three or four in popularity'. ${ }^{85}$

Between Brussels and Paris there had been a dual shift towards presenting Swedish democratic society and framing the project as an exercise in modern advertising. There was a general consensus among the organisers that both these moves were sensible. However, as the project was realised, its many vocal critics in the Swedish press argued that the pavilion had failed to achieve a balance between the two by overemphasising its political agenda. Still, the debate centred not so much on the value of advertising - 'admen' were always part of the organising process - but on what advertising actually meant. As the concept was applied in an increasing number of contexts, what in fact characterised 'modern advertising' was inevitably interpreted differently: some advertisers were utopian artists, others technocratic economists; some conceived their competence in terms of social engineering others as a means of constructing 'brand personality'. ${ }^{86}$ These differences played out in the succession of national pavilions analysed here. In Paris, Lind and his colleagues used advertising techniques to construct an international version of the Swedish Social Democratic project. They saw the staging of Swedish social reformism and the engaging of French publics as an extension of similar exhibition projects at home in Sweden. However, Stenbeck and his fellow advertisers at the helm in New York used advertising techniques to stage contemporary Swedish society as relatable and attractive to outsiders. The pavilion was not conceived as a political project in itself but rather as an engaging representation of one. In the 'social exhibition' in Paris, the slogan 'the Swedish people united in work' articulated a (party) political agenda. In the 'idea exhibition' in New York, the slogan 'Sweden - built in freedom' communicated a democratic national persona.

Nevertheless, overall there was general agreement within the committees, their most influential reviewers and prominent funders that effective propaganda for Sweden could neither be reduced to the crass rhetoric of sales nor to jingoistic boastfulness. Rather, the discussions both in the press and among committee members concerned getting the balance right between attracting attention and creating trust, between entertaining and educating. Although generally positive in his review of the New York pavilion and the 'self-conscious humility' on display, Gotthard Johansson for instance reflected that as 'finely embroidered' as the pavilion's presentation of social problems was, 'like commercials for a fashion house', there was 'still something lacking: the suggestive image, slogan, the selling point, [to use] the language of advertising. ${ }^{87}$ The challenge was to adjust statistics and exhibition aesthetics to the visitors' expectations of experiencing 'shock and captivation' at the fairs. ${ }^{88}$ A central tenet for achieving this effect was trying to gauge the visitors' reception of the pavilions. A significant move in this direction was introduced in Paris. Prompted by the onslaught of domestic criticism directed at the Swedish exhibit, the committee began to systematically monitor foreign reviews, both in French dailies as well as international specialist publications. Compendia of translated foreign press articles about the Swedish pavilion were then distributed by the committee to Swedish newspapers. Analysing foreign reviews can be seen as a form of what contemporary advertisers termed effect con$\mathrm{trol}$, the methods of opinion measurement used to objectively evaluate the effectiveness of campaigns.

The New York committee took the analysis of foreign receptions one step further, using it to influence other visitors. Not only were reviews in the US press used to evaluate the pavilion, but in June a rather lengthy selection of the most enthusiastic press reviews were incorporated into the exhibit's official booklet. In this way, positive reviews (often written by journalists first entertained by the Swedish press secretary or Secretary-General in the pavilion restaurant) were used to attract more visitors and

\footnotetext{
84 Harper's Magazine, July 1939; Haskell in The Nation, 20 May 1939. Both cited under 'American Comment' in Hedin, Sweden at the New York World's Fair, n.p.

85 See the press summary in the final report from the committee in charge of the Swedish Pavilion in 1937. For New York, see copywriter Gustafson to Chairman Ericsson, dated 27 June 1939; Ericsson to Möller, letter dated 19 May 1939, both Vol. 14, SNUY1939, RA.

86 Gardeström, Reklam och propaganda, chapter 3; Schwarzkopf, 'What was advertising?', 10-6.

87 'Sverige på Expo', Svenska Dagbladet, 3 May 1939. Italics (and the use of the English 'selling point') in the original.

88 'Paviljongen är inte det första', Reklamnyheterna, 30 Dec. 1938.
} 
frame their understanding of what made the Swedish exhibit unique. In Brussels in 1935, by contrast, there had been no systematic follow-up of reviews in the press and no attempt even to estimate how many people actually visited the Swedish pavilion. Over the course of only four years then, the masses at the fairs began to crystallise into sets of distinct publics. And they did not emerge alone: alongside them the public back home also entered the frame.

At the heart of the genre of 'idea exhibitions' lay the ambition to make the public aware of challenges in contemporary society and instigate public discussions about certain social issues. The New York pavilion introduced this genre into Sweden's cultural diplomacy abroad. Markelius's building in New York was explicitly said to place chief emphasis on its contents rather than on spectacular appearances: "Don't look at me", it seems to say, "look at what is shown inside", the official guide claimed. ${ }^{89}$ As we have seen above, one method for the Swedes to sustain discussions with and between visitors in 1939 was by conducting initial market research in the United States. In order to engage the public, it was deemed vital that the projection of Sweden concentrate on themes that concerned Americans. Another method was to refrain from claiming to have all the answers. ${ }^{90}$ In both 1937 and 1939 the message was that Sweden in its present state was by no means a finished product; the country still had room for urgent improvement. The guide book to the Paris pavilion earnestly declared, 'for our picture to be truly representative it must not only display the results achieved in the various spheres but must also show the nature of the problems we [still] have to contend with'. ${ }^{91}$ Echoing the pavilion displays in Paris, Minister for Social Affairs and Commerce Gustav Möller hammered home, in a speech at the fairgrounds in New York, that there were still 'many thousands of Swedes who are too poorly housed. And there are several hundreds of thousands whose income is still too low. ${ }^{92}$ According to many commentators, this realistic approach set the Swedish self-presentation apart from the boastful grandeur of surrounding exhibits. ${ }^{93}$ The renowned Swiss architectural theorist Sigfried Giedion suggested that the Swedes' 'display of problems (rather than selfpraise) should constitute a guideline for future exhibitors. ${ }^{94}$ From the organisers' perspective, the chosen approach required close considerations of the intended visitors' frames of reference. During the planning of the social section in New York Bertil Ohlin worried about how a presentation of the living standard of Swedish workers might be misinterpreted as dismally low by the US public, while Consul General and businessman Josef Sachs - who had also chaired the lambasted Paris pavilion committee - was just as concerned about how it would be interpreted by Swedes. He was adamant that any displays about living standards must take both Swedish and US publics into account. ${ }^{95}$ As Sven Ivar Lind would be the first to admit, the challenge of employing the rhetoric of honesty lay in the diversity of the visitors' backgrounds: what foreign visitors found refreshingly frank, many Swedish observers found unnecessarily self-derogatory.

We have above sought to show how, at the spectacle-packed world's fairs in Paris and New York, the Swedes sought to make level-headed democratic discussion their national niche. This effort demanded a considered utilisation of modern advertising techniques and proven methods of 'propaganda'. It was an endeavour not only full of paradoxes but also risk, as involving the press and 'the people' was a conscious part of the strategy of (re)presenting democracy. This strengthened the

\footnotetext{
89 Hedin, Sweden at the New York World's Fair, n.p.

90 See Marklund, 'The Social Laboratory, the Middle Way and the Swedish Model: Three Frames for the Image of Sweden', Scandinavian Journal of History, 34, 3 (2009).

91 Stavenow, ed., International Exhibition Paris 1937, 11. This paragraph was an almost verbatim rendering of Myrdal's first outline for the social section.

92 '10,000 mark is passed at fair', New York Times, 26 June 1939.

93 Such foreign comments were cited in, for example, 'Sveriges paviljong på Parisutställningen', Byggmästaren, 16, 32 (1937), 339 ff, and under 'American Comment' in Hedin, Sweden at the New York World's Fair.

94 Sigfried Giedion, 'Kritisches zur Weltausstellung', Die Weltwoche, 30 July 1937, cited in 'Sveriges paviljong på Parisutställningen'.

95 'Protokoll av diskussion i samband med visning av utställningsmodellen för Verktställande utskottet och sektionsmedlemmarna', 14 Oct. 1938, Vol. 1, SNYU-1939, RA.
} 
legitimacy of the pavilions but left them open for public criticism. As one member of the Paris committee observed: 'a portrait is seldom liked when it provides honest characterisation without embellishment. At least not by the model. ${ }^{96}$

\section{Conclusion}

In January 1945, with the end of the Second World War in sight, Sweden's official cultural diplomacy was boosted and centralised with the foundation of the Swedish Institute for Cultural Exchange with Foreign Countries. The pre-war institutional roots of the institute and its activities have quite rightly been traced to the establishment in 1935 of the Enlightenment Board (Upplysningsnämnden), which during its short lifespan was primarily concerned with academic exchange matters as a result of the rapidly changing political environment for Swedish lecturers working abroad. ${ }^{97}$ Here, however, we have pointed to an additional institutional trajectory, also starting in the mid-1930s, which was organisationally separate and financially more prioritised than the Enlightenment Board: the production of politico-didactic exhibitions for foreign publics. From its start in 1945 the Swedish Institute was charged not only with projecting and presenting the Swedish nation but also the state. This central pillar of its mission, and the way it was articulated in accessible exhibitions and publications, was rooted in the experience of Sweden's pavilions in Paris and New York. That work had trained Swedish elites to sensitively gauge foreign public interest in Sweden and provided practical experience of how diplomatic, commercial and scholarly interests could be coordinated to accommodate it. One direct consequence was that the domain of the 'cultural exchange' referred to in the Swedish Institute's name was stretched from the outset to include the promotion of Swedish consumer goods as well as portrayals of Swedish social reforms, economic policy and the living standards of Swedish labourers. In the words of its Deputy Director, the Institute's remit was 'cultural exchange in its broadest sense. ${ }^{98}$

By concentrating on this early institutionalisation of Swedish cultural diplomacy, this article makes two important contributions. First it shows how diplomacy and advertising merged in the Swedish context to affirm Sweden as a point of reference in the welfare state 'mental maps' of interwar Europeans and North Americans. ${ }^{99}$ While foreign journalists such as Schreiber and Childs were establishing Sweden as an example of successful handling of economic and socio-political crisis, a loose but quite efficient and well-connected network of communicators formed in Sweden to set about popularising these themes and packaging them for mass consumption. This network was generously supported with state funds, and its activities should therefore be seen as part of the government's diplomatic response to the political and economic crises of the 1930s. The network brought the managers of established, big industry at the SGEA into the orbit of the politically radical modernist architects and designers of the Swedish Arts and Crafts movement and the media-skilled advertising professionals. At times it engaged academics like Myrdal and Bonow, other times it congregated round the elevated status of royalty such as Count Bernadotte, or connected with the well-oiled machinery of the Swedish-American News Exchange. The ideas and practices of several key figures that formed the central node of this network have been studied by historians concerned with the domestic Swedish context. Here we have shown how, over a period of just a few years, they established themselves as a major influence on how the nation was officially projected abroad. Moving into the international arena they remained committed to the general politico-didactics of public exhibitions that had been staged in Sweden: that they should function both as 'a learning platform and a campaign

\footnotetext{
96 Hakon Ahlberg, 'Sveriges paviljong på Parisutställningen', Byggmästaren, 16, 31 (1937), 341.

97 Åkerlund, Mellan akademi och kulturpolitik; Åkerlund, 'The Nationalisation'.

98 'Några drag ur Svenska institutets verksamhet', speech at the Annual Meeting of the Council for the Swedish Institute for Cultural Exchange with Foreign Countries, 14 Oct. 1946, Series BIV, Vol. 1, Svenska institutet för kulturellt utbyte med utlandet, RA; Nikolas Glover, 'Imaging Community. Sweden in "Cultural Propaganda” Then and Now', Scandinavian Journal of History, 34, 3 (2009). See also Andreas Mørkved Hellenes, 'Institut suédois et images de la Suède à Paris dans l'après-guerre', Revue d'histoire nordique, 19 (2014).

99 Patel, The New Deal, 228.
} 
vehicle'. ${ }^{100}$ There were at times significant professional and ideological conflicts internally within the network, but an emerging rule was that claiming to master the imperatives of modern advertising was an effective way of wielding influence. The furore over the Paris pavilion that leading advertisers created clearly paved the way for the decision to place the methods of 'modern advertising' at the centre of the plans for New York.

Second, this article contributes to literature on the world exhibitions with a case study of how representatives of a small country over the course of three fairs responded to, and used, the evolving trends at these international mega-events. The Swedish pavilions' migration from industrial to socio-political reflected the increased involvement of the Swedish state, and the experience set a precedent for the direction of its future post-war cultural diplomacy. Even if each pavilion was temporary, the congested schedule of Brussels (1935), Paris (1937) and New York (1939) meant that the committee work within Sweden was practically permanent. Although every committee was assembled slightly differently (some members never changed), there was in each case an attempt to learn from previous experience and deploy those insights in the next project. The attention of the organising committees was primarily directed towards avoiding the mistakes of their predecessors, keeping pace with national developments in exhibition trends and eyeing what other, comparable, 'small countries' were planning. There was little point in attempting to predict or emulate the grandstanding of the big powers. Moreover, whereas previous scholarship has highlighted how major countries at the interwar world's fairs competed by projecting national versions of modernity, this study shows that smaller ones were working on the periphery to offer glances of lesser-known alternatives. Because of their budget constraints, the Swedish pavilion committees spent much of their energy on finding a consistent, attractive form to the pavilions, designing exhibitions that made a virtue of Sweden's relative smallness and unassuming global standing. In the words of one of the pavilion staff in New York, 'we are not boisterous and will not be noticed for having a violent tone, but we are intimate'. ${ }^{101}$ The positive reception in the French and US press and the millions of visitors visiting the pavilions suggests that this proved to be quite effective. The pavilions sought to fuse the socio-political interest in Sweden with the growing reputation of Swedish decorative arts and design, a combination that was fortuitous in the world's fair context: while the latter appealed to visitors as consumers, the former spoke to them as citizens. Taken together they constituted a perfect fit for what has been called the 'touristic consumerism' of world's fairs, 'a popular cultural version of internationalism'. ${ }^{102}$

In the heady but threatening atmosphere of the late 1930s the themes of Swedish pavilions in 1937 and 1939 were in part an attempt at democracy activism in the global arena, staking out a path away from totalitarianism. To an equal degree they were the result of a successful professional sales pitch by promotional communicators establishing their position within Swedish society. Whichever aspect is emphasised, from a broader perspective the pavilions were the expression of one small state's attempt to seize the opportunities opened up by the crises of capitalism and democracy.

Acknowledgements. Nikolas Glover's research has been funded by Jan Wallanders och Tom Hedelius stiftelse (Project P2016-044:1). Andreas Mørkved Hellenes's research has been funded by Vera och Greta Oldbergs stiftelse and the Independent Research Fund Denmark (Project 8018-00023B). Earlier versions of the article were presented at the International History of Public Relations Conference at Bournemouth University (2018) and the New Diplomatic History Network Conference in Middelburg (2018). We are grateful for the comments from colleagues at these conferences and from three anonymous reviewers. Warm thanks also to Benjamin Martin and Elisabeth Piller for their astute reading and generous advice along the way.

100 Lundgren, 'Making Society', 67.

101 Svea Lindstrand, 'Veckorna . . . dagarna . . . timmarna före', Form, 35 (1939), 141.

102 Maurice Roche, 'Mega-Events, Culture and Modernity: Expos and the Origin of Public Culture', International Journal of Cultural Policy, 5, 1 (1998), 20.

Cite this article: Glover N, Hellenes AM (2021). A 'Swedish Offensive' at the World's Fairs: Advertising, Social Reformism and the Roots of Swedish Cultural Diplomacy, 1935-1939. Contemporary European History 30, 284-300. https://doi.org/ $10.1017 /$ S0960777320000533 